\title{
A Life Cycle Comparison of Remote, Deployed Expeditionary Waste Management Scenarios
}

\author{
David Chester, Chandrani Mukherjee, Jeremy Slagley*, Eric Mbonimpa, \\ Thomas Hornstein \\ Department of Systems Engineering and Management, Air Force Institute of Technology, Wpafb, OH, USA \\ Email: ^Jeremy.Slagley@afit.edu, Eric.Mbonimpa@afit.edu
}

How to cite this paper: Chester, D., Mukherjee, C., Slagley, J., Mbonimpa, E. and Hornstein, T. (2021) A Life Cycle Comparison of Remote, Deployed Expeditionary Waste Management Scenarios. Journal of Environmental Protection, 12, 141-159. https://doi.org/10.4236/jep.2021.122010

Received: December 24, 2020

Accepted: February 23, 2021

Published: February 26, 2021

Copyright () 2021 by author(s) and Scientific Research Publishing Inc. This work is licensed under the Creative Commons Attribution International License (CC BY 4.0).

http://creativecommons.org/licenses/by/4.0/

\begin{abstract}
The current barrier to acquisition and utilization of viable waste-to-energy (WTE) technologies at remote or deployed expeditionary sites requires high capital and operation \& maintenance costs. The impacts to environment and human health of differing expeditionary waste management strategies were compared using the Life Cycle Assessment software SimaPro 8.0. Emissions of individual waste management scenarios were compiled from peer-reviewed literature, converted to values compatible with SimaPro's waste scenario inputs, and the calculated impacts compared using SimaPro's pre-loaded methodologies. These calculated impacts and the economic impacts confirm that open-air burning of waste is not only dangerous to humans and the environment, but is also not cost-effective. Considering the economic effects and the mitigated human and environmental health impacts, WTE technologies may be a viable waste management strategy for the future.
\end{abstract}

\section{Keywords}

Life Cycle Assessment (LCA), Municipal Solid Waste (MSW), Incineration, Sanitary Landfill, Open Burn Pits

\section{Introduction}

Waste is an inevitable byproduct of life. The management of waste is extremely important as poor waste management is known to have adverse human health and environmental health effects, and aesthetic impacts [1]. The need for improved municipal solid waste (MSW) management techniques is even more urgent in remote military bases and deployed environments with limited land and energy resources to dispose of MSW [2]. Current waste disposal practices for United States (US) Department of Defense (DoD) contingency military bases 
involve trucking away waste or bringing in additional fuel to burn the waste in open burn pits, adding to the transportation burden and increasing risk to personnel [2] [3]. As of March 2020, over 199,000 Veterans and service members voluntarily registered with the US Department of Veterans Affairs (VA) in the Airborne Hazards and Open Burn Pit (AH\&OBP) Registry to report exposure to the open-air burning of waste, a fraction of the estimated 3.5 million individuals eligible to participate in the registry [4] [5]. A report on the AH\&OBP Registry found that registry participants who reported exposure to burn pits had higher prevalence of asthma, high blood pressure, chronic obstructive pulmonary disease (COPD), chronic bronchitis, and emphysema than those with no exposure [5]. An estimated 3.5 million service members may have been exposed to openair burn pits and may experience adverse health conditions in the future, resulting in significant overall medical costs.

The disposal of waste in a sanitary landfill is a generally accepted waste management strategy, but the 30-year post-closure care requirements are too great a commitment for contingency bases [6]. Current US military expeditionary waste management options therefore utilize built incinerators, contract waste services with the host country, or burn the waste in open-air burn pits. Open-air burn pits are discouraged and congressionally required to be eliminated [7].

To achieve a net zero consumption of energy in the disposal of waste while maintaining compliance with air quality standards, the focus of waste management is moving more towards waste-to-energy (WTE) systems [2] [3] [8] [9] [10] [11]. Thermal WTE treatment options are presently underestimated as a potential waste reduction and alternative energy method. The most widely used thermal WTE is incineration of MSW. It is a relatively mature technology for biomass feedstock conversion and commercially used as a source of renewable energy in many developed countries, including but not limited to: Sweden, Germany, Japan, Korea, China, and even the US [8] [12]-[17]. Previous studies have used life cycle assessment (LCA) to compare various waste management options (Fernández-Nava et al., 2014; Giugliano et al., 2011), however LCA of waste management scenarios at expeditionary and remote installations, such as military and disaster relief camps, has not been fully explored. This paper studies the environmental implications of four waste management options: WTE incineration, sanitary landfills, local host country unregulated landfills, and open burn pits. A life cycle assessment (LCA) using the Tool for Reduction and Assessment of Chemicals and Other Environmental Impacts (TRACI) methodology was used to carry out this comparative analysis.

\section{Material and Methods}

This methodology outlines the creation of the waste treatment scenarios in $\mathrm{Si}$ maPro for comparison via LCA. It follows the LCA framework by first defining the scope of the LCA. After determining the goal, the scenario boundaries and the functional unit of the LCA are defined, and data for the scenarios is collected 
for the inventory analysis. Data for inputs and emissions for the four waste scenarios is compiled from research and converted to SimaPro-ready values (Appendix B in Supplementary Data). A life-cycle impact assessment is then conducted using SimaPro's TRACI 2.1 impact assessment tool.

\subsection{Life Cycle Assessment}

An LCA is a useful tool to evaluate the environmental impact of MSW management systems [18]. The LCA is a compilation and evaluation of the inputs, outputs and the potential environmental impacts of a product system throughout its life cycle [19] [20]. The popularity of LCAs in analyzing MSW management systems is illustrated by the numerous published studies addressing MSW management [21]. Environmental life-cycle analysis, also known as life-cycle assessment, is a systematic tool or framework used to identify and evaluate the environmental impacts associated with the energy and resources to create materials or services throughout the product's entire lifespan [20] [22]. LCA generally follows the International organization for Standardization (ISO) published framework: 1) Define goal and scope, 2) Inventory analysis, 3) Life cycle impact assessment (LCIA), and 4) Interpretation.

The first and arguably most important step is to define the scope of the LCA. This involves setting clear boundaries of the investigated system, allowing the quantity and quality of inputs and outputs across this boundary to be measured. The life cycle inventory analysis is the data collection on the use of energy and materials for the product or service. The life cycle impact assessment (LCIA) uses the inventory data to sum the resources and energy consumed and wastes emitted by all processes in the system to estimate potential impacts to the environment. Interpretation of these results allows decisions to be made to reduce potential impacts by changing energy or material sources or updating processes or to decide between products or services [20] [22].

Although LCA is an integrated approach of the four phases for estimating the environmental implications of a process, the quality of output depends on the assumptions made, input data, and limitations of the methodology used [23]. An LCA can be run using deterministic input values or if uncertainty around inputs is known a stochastic analysis using techniques such as Monte Carlo simulations can be accomplished. This was a comparative analysis using deterministic information from operational theater and literature, no stochastic simulation was conducted due to lack of uncertainly information around input values.

The LCA software used in this study, SimaPro, is structured to pull materials, energy, and emissions inventories of processes and products from one of its databases (e.g. Eco-Invent). It then aggregates these inventories over the life cycle of the product or the process. It then uses user-selected method (e.g. TRACI) to calculate environmental impacts associated with the inventories [24]. In SimaPro, the end-of-life of a product can be modeled using waste scenarios and waste treatment processes. Waste treatment accounts for the emissions and impacts 
generated from landfilling, burning, recycling, or composting of wastes whereas scenarios just track material flow [25] [26]. A modeler can use pre-installed or custom waste treatment scenarios; given the mass of treated waste energy, fuel, and emissions are calculated or can be defined.

To perform impact assessment, the Tool for Reduction and Assessment of Chemicals and Other Environmental Impacts (TRACI) method was selected. TRACI classifies environmental impacts in various categories, each in units of an indicator substance equivalents: Ozone depletion in $\mathrm{kg}$ chlorofluorocarbons (CFC-11), Global warming in $\mathrm{kg} \mathrm{CO}_{2}$, Smog in $\mathrm{kg} \mathrm{O}_{3}$, Acidification in $\mathrm{kg} \mathrm{SO}_{2}$, Eutrophication in $\mathrm{kg} \mathrm{N}$, Carcinogenics in comparative toxic units (CTU) for humans (h) morbidity), Non-carcinogenics in CTUh, Respiratory effects in kg particulate matter-PM, Ecotoxicity in CTU for aquatic ecotoxicity (CTUe), and Fossil Fuel Depletion in MegaJoules-MJ [25] [26].

For visualization, SimaPro uses normalization factors to compare different impact categories. The normalization divides each impact category's output with the average yearly impact values of a US or Canadian citizen for each impact category. Each bar on the visualization figure is scaled based on the impact of an average US or Canadian citizen [25] [27]. On results' figures the scenario with the highest impact is set to 100 and other scenarios are scaled relative to this highest scenario.

\subsection{Goal and Scope Definition}

The objective of this LCA study was to compare the environmental, human health, global warming, and economic impacts of existing US Department of Defense (DoD) expeditionary waste management techniques. Parameters such as transportation, landfill leachates, and air emissions were also considered along with impact on human health and environmental health. In this analysis, four different waste management scenarios were investigated:

Scenario 1: WTE Incinerator-an incinerator with potential for energy capture and controlled air emissions.

Scenario 2: Contracted (distant) sanitary landfilling.

Scenario 3: Local (unregulated) landfill or contracted local waste managementwithout landfill gas recovery or leachate capture.

Scenario 4: Open burn pits or open-air burning of waste.

For each scenario, a detailed life cycle impact assessment (LCIA) was used to determine the environmental emissions. In deciding the scope, waste collection procedures should be considered as the trucks, fuel, route distance, etc., all contribute to the LCIA. However, in all scenarios, waste from all base tenants was assumed to be collected similarly. This impact is therefore the same across all scenarios and can be removed from consideration. The boundary of all four scenarios commenced with all base wastes collected at a single waste collection point and then all energy, resource inputs, and emissions were considered, until the final disposal of the waste. To allow for meaningful comparison between strategies, the functional unit of comparison was $1 \mathrm{~kg}$ of generic waste. For all 
scenarios, all impact and emission calculations were for the disposal of $1 \mathrm{~kg}$ of waste in an expeditionary environment. A combination of SimaPro's available inventory data on waste treatment requirements and emissions, and emissions data collected from relevant literature were used in the construction of the four modeled scenarios. Also, a major assumption was ignoring the material inputs required to build the incinerator at the deployed location.

The selected study site for this LCA is a mock US military waste scenario in southern Afghanistan. Simplifying assumptions were made in this LCA study. SimaPro's impact calculations are additive vice computational, meaning the addition of material, energy, or processing to a waste management scenario does not change the currently computed impact, but simply adds the impact of the added material, energy, or processing to the current computation. The outputs from SimaPro are calculated using SimaPro's pre-installed TRACI 2.1 methodology. The discrete impact values are calculated using SimaPro's pre-installed exposure assumptions, but their importance is minimal without a means for comparison. A process producing 1 million $\mathrm{kg}$ of $\mathrm{CO}_{2}$ means the process is detrimental to global warming. However, if the process is a replacement to the 100 million $\mathrm{kg}$ of $\mathrm{CO}_{2}$ of the current process, it is then a comparative improvement. This study compares the relative impact results between the waste management scenarios using the same TRACI 2.1 methodology and exposure calculation so that meaningful qualitative comparisons can be drawn between the scenarios.

Despite the collection and use of real data in the creation of the waste treatment models, these data points represent values at a very specific point in time, with specific meteorological conditions, and are generated from a specific waste profile. There always exists some degree of uncertainty (degree of difference from the real-world scenarios) in the LCA models in spite of averaging multiple data points to build the representative waste models. The use of estimates in calculations with estimates of exposures only serves to compound this potential difference. Attempts to minimize the effects of these differences included using the same methodology to calculate impacts in all scenarios, maintaining a comparable and representative scope, and keeping analysis and interpretation to reasonable qualitative comparisons between the four scenarios.

\subsection{Life Cycle Inventory}

\subsubsection{WTE Incinerator Air Emissions (Scenario 1)}

The WTE incinerator model assumed herein overlooked construction of the incinerator facility, and its operation and maintenance. Transportation from the waste collection point to the incinerator is also considered negligible. The model captures the energy input requirements to operate the incinerator including waste homogenization and flue gas treatment, emissions to the air, and required storage or disposal of incinerator residuals like slag or ash. SimaPro is equipped with multiple incinerator models that consider the inputs, emissions, and avoided products from energy generation from the WTE system. A comparison of three pre-installed WTE incinerators was made in SimaPro to select an appropriate 
alternative for scenario 1 :

1) "Municipal Solid Waste (RoW)|treatment of, incineration"-This alteration uses data representing the activity of waste disposal of MSW in a waste incinerator for average municipal/communal waste mixtures. The rest of world (RoW) label represents a global data-set and represents activities considered to be an average valid for all countries in the world [28].

2) "Waste incineration of municipal solid waste EU-27"-This alteration represents the incineration of MSW in an average European WTE plant and includes flue gas treatment and nitrogen oxides (NOx) removal technologies. The model assumes the generation of 1.09 GJ electricity per ton of incinerated MSW.

3) "Waste incineration of municipal solid waste EU-27 S"-This scenario uses an update to the average European WTE plant with the separation of certain waste fractions like glass. The model includes flue gas treatment and NOx removal technologies. The model also assumes the generation of $1.09 \mathrm{GJ}$ of electricity per ton of incinerated MSW.

Across all categories, the RoW incinerator had the highest calculated impacts values (Appendix A in Supplementary Data). This is due to the lack of flue gas treatment before emission and the lack of captured energy offsetting fossil fuel generated energy. The updated European WTE incinerator accounts for increased efficiencies in the incineration process, and the avoided emissions from the generated electricity create "negative" impacts as the generated electricity lowers the requirement for fossil fuel-derived electricity sources with their own environmental impacts. Of the available models, the RoW incinerator was the most likely accurate, available model to simulate emissions and impacts for an incineration technology in an expeditionary environment, so it was selected as the WTE alternative for scenario 1 .

\subsubsection{Distant Sanitary Landfill Emissions (Scenario 2)}

The second disposal scenario is the contracting of sanitary landfilling for the waste. It was assumed that the sanitary landfill was in a distant location such as a neighboring country. While contracted services present security concerns for remote deployed military bases, the disposal of waste in sanitary landfills with landfill gas and leachate capture may offset many environmental impacts. The scenario assumed that the waste was collected from the collection point and delivered to the sanitary landfill with all emissions and energy requirements for the transportation and the operation of the landfill. In the US Central Command (CENTCOM) area of responsibility (AOR), specifically southern Afghanistan, sanitary landfills are hard to come by, requiring transportation to Kabul or Iran [29]. The model assumes a conservative, one-way $400 \mathrm{~km}$ distance of transportation in a refuse truck to the nearest sanitary landfill and takes advantage of SimaPro's installed sanitary landfill waste treatment scenarios. Two potential landfilling alternatives were compared:

1) "MSW (RoW)|treatment of, sanitary landfill, distance haul"-The sanitary landfilling of waste averaged for the RoW with the required $400 \mathrm{~km}$ transporta- 
tion in a refuse truck.

2) "MSW (RoW)|treatment of, sanitary landfill"-The sanitary landfilling of waste averaged for the RoW without the transportation.

Due to the additive nature of SimaPro, the addition of the transportation to the waste disposal scenario had additional impacts in all categories. The impact values are outlined in Appendix A in Supplementary Data. The required diesel fuel for the transportation vehicle contributes significantly to smog production, acidification, and fossil fuel use, but contributes only a minor amount to the remaining categories. For a 19-tonne (21-ton) refuse truck hauling MSW for 400 $\mathrm{km}$, assuming a conservative $2.6 \mathrm{~km} / \mathrm{L}(10 \mathrm{kmpg})$, the required fuel is only $7.9 \mathrm{~L}$ per tonne (1.9 gallons per ton) of MSW. The requirement to transport the waste to a sanitary landfill is extremely likely due to southern Afghanistan's lack of sanitary landfills, and therefore the impacts including transportation are a more accurate representation of impacts for this waste treatment scenario 2 .

\subsubsection{Local Unregulated Landfill Emissions (Scenario 3)}

The third available waste treatment scenario was also contracting waste disposal services, but with a local landfill. It is already assumed that sanitary landfills in southern Afghanistan do not exist, and therefore the assumption was that a local landfill would not have landfill gas or leachate capturing. SimaPro does not contain data for models of unregulated landfills, and therefore a representative waste treatment scenario was constructed from available data. Some assumptions were made on the emissions of unregulated landfills, specifically that the make-up of landfill gas and leachate was the same between regulated to unregulated landfills. The only difference being that sanitary landfills engineer mechanisms to capture these emissions for treatment. This is likely a conservative assumption because the turning and layering of soil in sanitary landfills creates an environment with pressure and temperature different from an open-air environment, but allows the use of available literature on the chemical make-up of landfill gas and leachate to construct the model. A second assumption was the transportation requirement for a local landfill was negligible from the base collection point.

Data from published sources on landfill gas and leachate make-up was aggregated and converted to SimaPro input values in Supplementary Data Appendix B [30]-[38]. For landfill gas, an EPA model allowed the prediction of landfill gas volume per unit MSW in an arid environment per year, and the contaminant emission data given in concentrations was converted to a unit mass of contaminant (in g) per unit mass of MSW (in kg) using the ideal gas law. An example calculation for mass of emitted $\mathrm{CO}_{2}$ per $\mathrm{kg}$ of landfilled waste is below. The average measured concentration of $29.45 \% \mathrm{CO}_{2}$ by volume at 1 atm and $25^{\circ} \mathrm{Cel}-$ cius yields:

$$
\text { Mass }=(P * V * M W) /(R * T)
$$

$$
P=\text { Air Pressure (atm) }
$$


$V=$ Gas Volume (L)

$M W=$ Molecular Weight (g/mole)

$R=$ Ideal Gas Law Constant $\left(\operatorname{atm}^{\star} \mathrm{L} / \mathrm{mol}^{\star} \mathrm{K}\right)$

$T=$ Temperature $(\mathrm{K})$

Using Equation (1),

$$
\begin{aligned}
\text { Mass }= & \left(1 \mathrm{~atm} \times 0.2945 \times 6.5 \mathrm{~m}^{3} / \mathrm{Mg} \times 44 \mathrm{~g} / \mathrm{mol}\right) /(0.08206(\mathrm{~atm} \cdot \mathrm{L}) /(\mathrm{mol} \cdot \mathrm{K}) \\
& \times 298.15 \mathrm{~K}) \times \mathrm{Mg} /\left(10^{3} \mathrm{~kg}\right) \times\left(10^{3} \mathrm{~L}\right) / \mathrm{m}^{3} \\
= & 3.443 \mathrm{~g} /(\mathrm{kg} \text { waste })
\end{aligned}
$$

For landfill leachate, a conservative estimate of landfill leachate per unit mass MSW was assumed for the arid climate of southern Afghanistan [39] [40] [41]. The concentrations of contaminant per liter of leachate were converted to masses of contaminant per mass MSW by dividing by the estimated leachate volume. The four unregulated model alternatives compared were:

1) "Unregulated Landfill"-Unregulated landfill model including emissions to air as landfill gas and emissions to groundwater as leachate.

2) "Unregulated Landfill (longterm emissions)"-The same unregulated landfill model including air and groundwater emissions, but impacts calculated for "long-term emissions" via SimaPro's pre-installed methodology.

3) "Unregulated Landfill (no leachate)"-Only landfill gas air emissions.

4) "Unregulated Landfill (no leachate/longterm emissions)"-Only landfill gas air emissions with "long-term emissions" for more than 100 years were used in calculations. The ecoinvent database in SimaPro considers emissions that occur over large time frames of substantially more than 100 years as "long term".

The calculated impact values are listed in Appendix A in Supplementary Data. The impact values for six of ten categories are identical, with significant changes in the remaining four categories due to either inclusion or exclusion of leachate emissions. These categories are eutrophication, carcinogens, non-carcinogens, and ecotoxicity. Per SimaPro's outputs, the sharp drop-off in calculated eutrophication impacts is due to removing the significant biological and chemical oxygen demand from nitrogen and phosphorous leaching into the ground water. The drop in carcinogenic toxicity impact is due to removing the chromium, lead, benzene, and toluene from leaching into the ground water. The drop in non-carcinogenic toxicity impact is due to removing the leaching of metals like zinc, cadmium, nickel, and copper into ground water. And finally, the drop in ecotoxicity impact is due to the same removal of metals from leaching into the ground water.

To assume that there will be absolutely no leachate reaching groundwater is a very conservative estimate, even for the desert climate in southern Afghanistan, and will therefore be kept in the model to capture these potential impact contributions. There is only a slight difference between short-term and long-term emissions in SimaPro's TRACI 2.1 calculated impacts in the non-carcinogenic category. Therefore, the selected unregulated landfill model was "Unregulated Landfill (longterm emissions)", which included leachate. 


\subsubsection{Open Burn Pit Air Emissions (Scenario 4)}

The final waste treatment scenario is the open-air burning of waste. It is assumed that this will take place on the base, and transportation from the waste collection point to the open-air burn pit is negligible. Due to the low-caloric value and typically high moisture content of MSW, the direct combustion of waste requires the addition of a substantial amount of fuel [2] [3] [16]. The model assumes a lower-end estimate of $204 \mathrm{~L}$ (54 gallons) diesel fuel per ton of waste, a stark contrast to Hornstein's assumed $3.8 \mathrm{~L}$ ( 1 gallon) of fuel per ton of waste [42], and some waste incinerators have shown to require much higher fuel to waste ratios, some reaching $579 \mathrm{~L}$ (153 gallons) of fuel per ton of waste [10]. After the direct combustion of material, there remains a volume of slag or ash. The model accounts for $30 \%$ non-combustible material by weight that must be landfilled [43].

Data from published sources is aggregated and converted to SimaPro input values in Supplementary Data Appendix B [44] [45] [46] [47] [48]. Papers sampled emissions from the open-air burning of waste and converted concentrations of contaminants to masses of contaminant by dividing by the measured air flow. These masses of emitted contaminants are then compared to the mass of waste combusted. These masses are averaged as unit mass contaminant emitted to air per $\mathrm{kg}$ waste burned. The considered open-air burn models alternatives were:

1) "Open Burn"- The constructed open-air burn model including air emissions from both the burning of waste and diesel fuel and includes the treatment of remaining ash in a landfill.

2) "Open Burn (no ash)"-The open-air burn model with air emissions from the burning of waste and diesel fuel but without the treatment of remaining ash in a landfill.

3) "Open Burn (no diesel)"-The open-air burn model with air emissions from only the burning of waste, not including the diesel fuel, and including the treatment of remaining ash in a landfill.

4) "Open Burn (no diesel/no ash)"-The open-air burn model with only the air emissions from the burning of waste, not considering the contributions from diesel or treatment of ash in a landfill.

Again, due to the additive nature of SimaPro's life-cycle impact assessments, the model that includes waste burning emissions, fuel use, and non-combustible material treatment has the highest impact across all categories (Appendix A in Supplementary Data). The removal of ash from the scope causes minor changes in seven of ten impact categories, but significantly lowers the impacts for eutrophication, carcinogenic, and ecotoxicity. This change is likely due to the highly concentrated and leachable nature of landfilled ash affecting groundwater. The diesel fuel requirement and its subsequent emissions are significant contributors to most impact categories, accounting for over half of the impact on five of the ten impact categories. The amount of diesel fuel selected for the model was a low-end estimate, and therefore these impacts are conservative estimates from fuel use. Because the fuel must be used in the open-air burning of waste, it is in- 
cluded in the selected model. The remaining ash in the bottom of the burn pit and the potential impacts of this ash are also included in the final model. Therefore the first model alternative, "Open Burn" was selected.

\section{Results and Discussion}

The life-cycle impact assessment found that open-air burn pits are the most negatively impactful waste management strategy in all categories: environmental health, and human health. While the remaining waste scenarios have similar human and environmental health impacts, WTE technologies are more cost effective than contracted services after 10 years.

\subsection{Life Cycle Impact Assessment}

The results of the life-cycle impact assessment between the four selected representative scenarios of expeditionary waste management are given in Figure 1. After comparing the human and environmental health implications of the waste management strategies, consideration was given to economics, reviewing potential costs, benefits, and mitigated costs.

Open-air burning of wastes has the highest impacts across eight of the ten impact categories (global warming, smog, acidification, eutrophication, carcinogenic, non-carcinogenic, respiratory effects, and fossil fuel depletion), significantly so in seven of those eight categories, and is a close second in the remaining two categories (ozone depletion and ecotoxicity). These calculated impact values are shown in appendix A in Supplementary Data. The results of the normalization for this comparison of four scenarios are shown in Figure 2.

Compared to the average impacts of US and Canadian citizens in 2008, the most detrimental impact categories are carcinogenics, non-carcinogenics, and environmental ecotoxicity, all shared by the open-air burning of waste. The LCA results point to the open-air burning of waste as the most harmful expeditionary

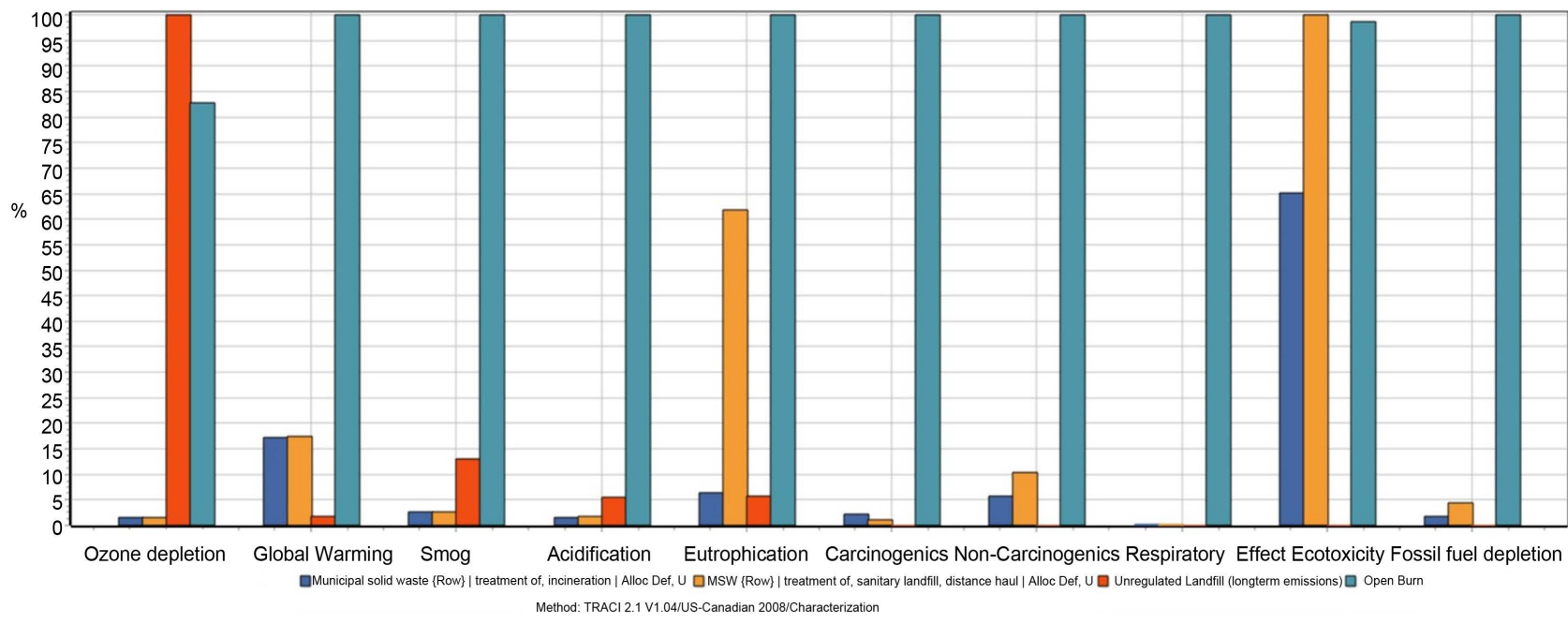

Figure 1. LCA characterization of four expeditionary waste management scenarios-WTE incineration, sanitary landfill, unregulated landfill, and open burn pit. 


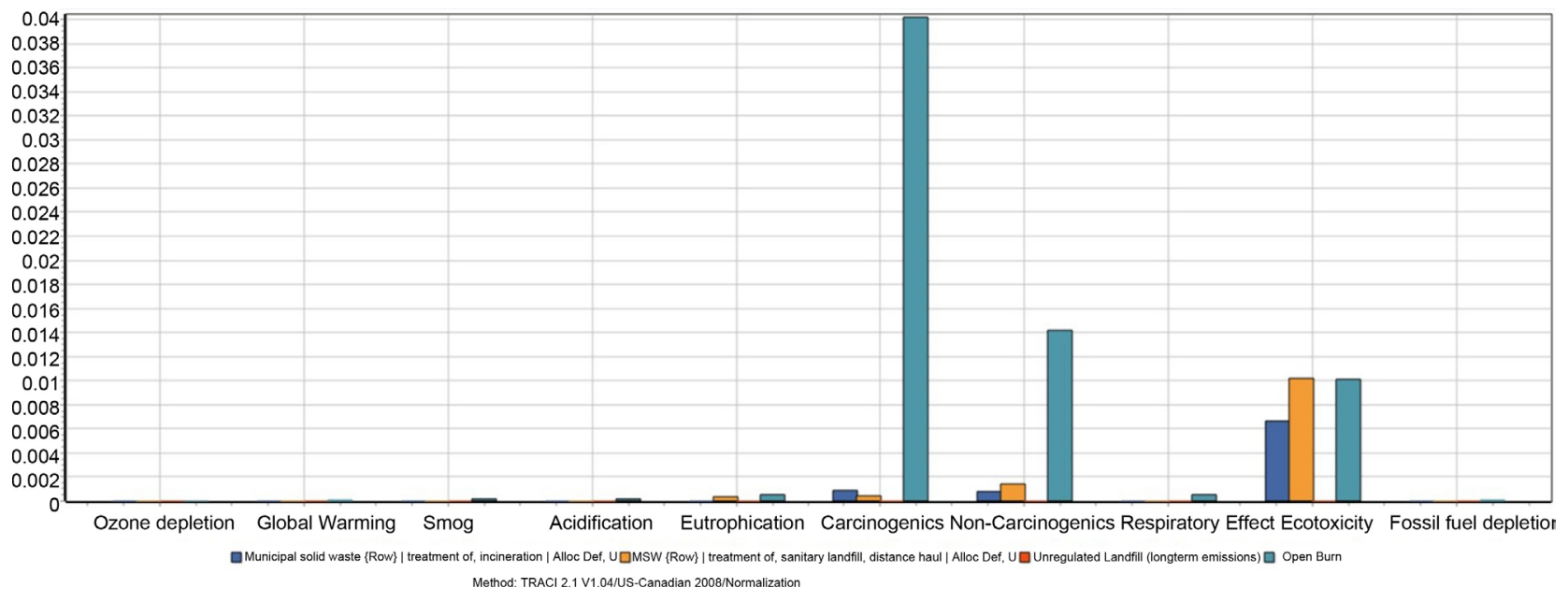

Figure 2. Normalization of four-scenario comparison.

waste treatment scenario to human and environmental health. The impacts dwarfed the other scenarios, so they were removed from the comparison for the next analysis to consider the other three scenarios. The results of an identical comparison, but with open-air burning removed from consideration, is shown in Figure 3.

Overall, the impact values compared between the remaining three waste treatments scenarios are closer than when open-air burning is considered. In this three-scenario comparison, the transportation and sanitary landfilling of wastes accounts for the highest impacts of six of ten categories (global warming, eutrophication, non-carcinogenics, respiratory effects, ecotoxicity, and fossil fuel depletion), and a local unregulated landfill accounts for the highest impacts in three categories (ozone depletion, smog, and acidification). The conversion of waste in a WTE incinerator is most impactful in only one category (carcinogenics), and a close second in a second category (global warming).

The high impacts for ozone depletion for unregulated landfills are directly caused by the releasing of chloroflurocarbons (CFCs) likely from refrigerants or propellants in the waste. In regulated landfills, open-air burn pits, and WTE incinerators, these CFCs are captured and/or combusted. The high impact results associated with ecotoxicity for landfilling, WTE incineration, and open-air burning are associated with the emission of heavy metals including copper, zinc, nickel, etc., into groundwater from landfilled material.

This impact assessment was normalized as shown in Figure 4. Relative to the average impacts of US and Canadian citizens in 2008, the most detrimental impact category was ecotoxicity. Also, the normalization shows that although unregulated landfilling is the most impactful waste management scenario in ozone depletion, smog, and acidification, these are relatively smaller impacts compared to ecotoxicity and carcinogenic and non-carcinogenic human health impacts.

At first glance upon Figure 4, an unregulated landfill in an arid environment appears to be the least impactful expeditionary waste management option in 


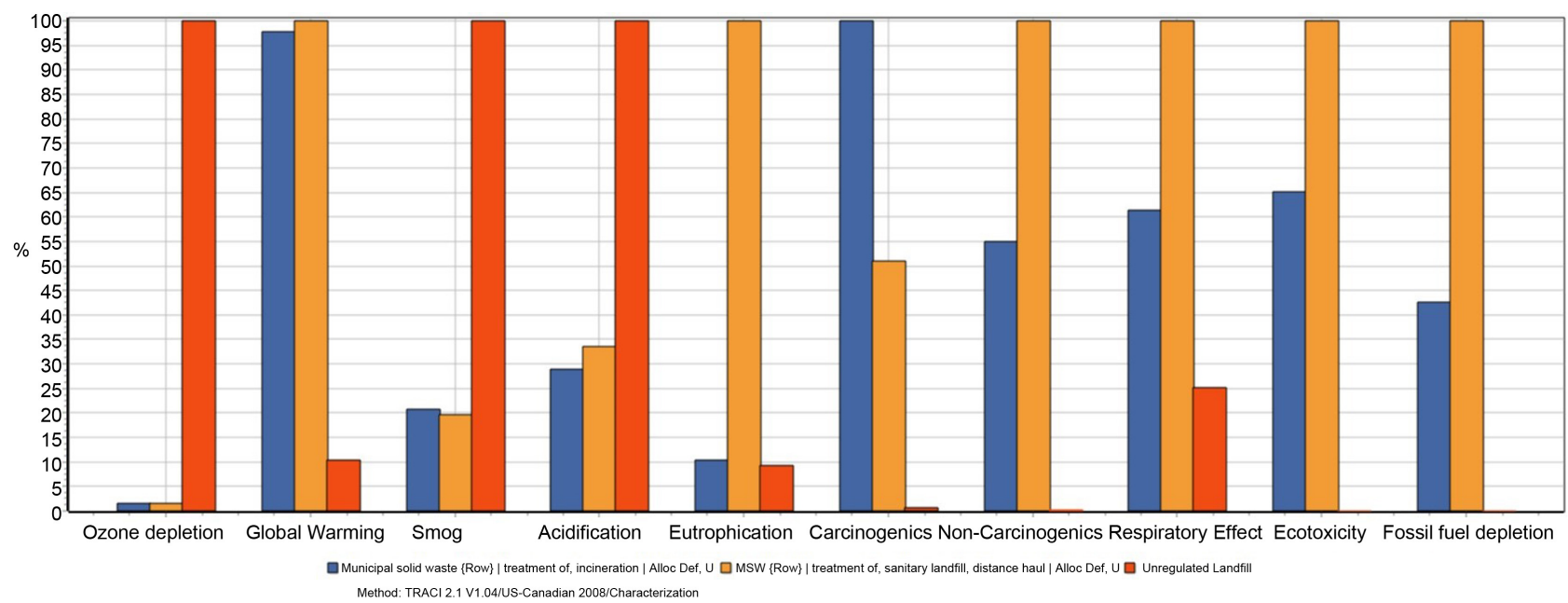

Figure 3. LCA characterization of the remaining three expeditionary waste management options-WTE incineration, sanitary landfill, and unregulated landfill.

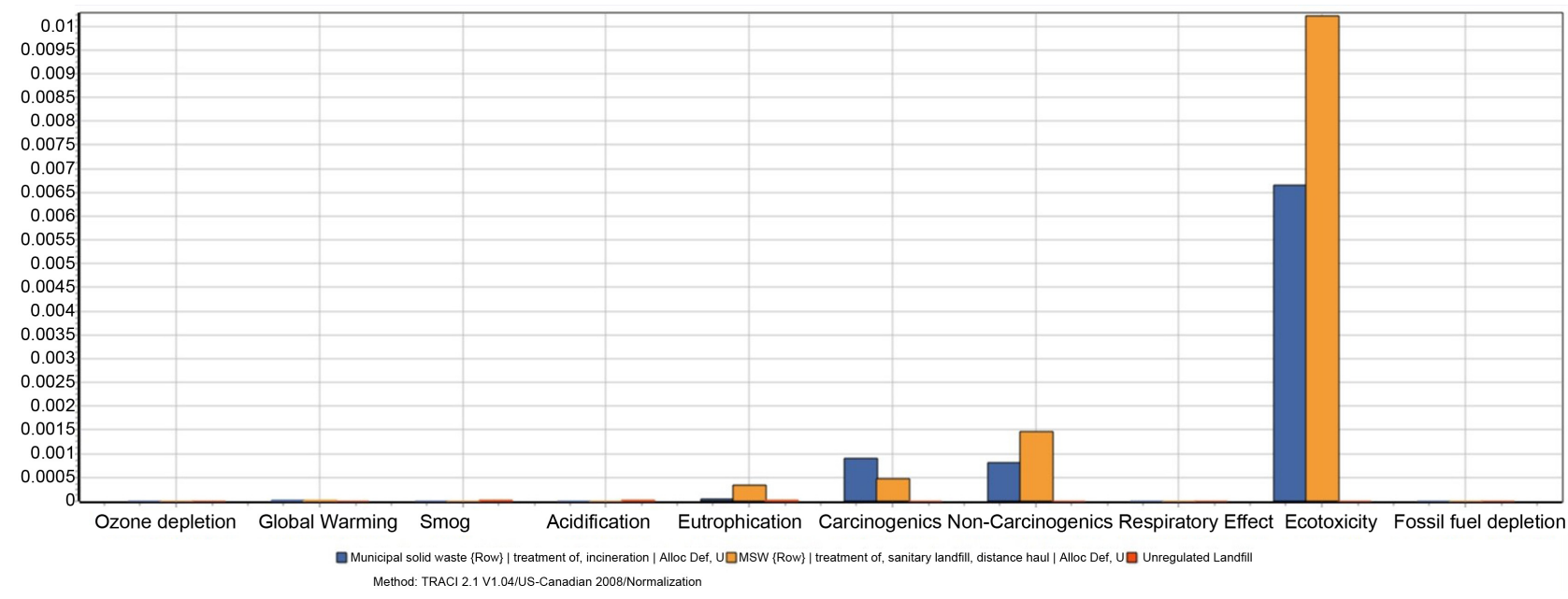

Figure 4. Normalization of the three-scenario comparison.

terms of human and environmental health, but aesthetic concerns, public perception, and the threat of diseases from pests and vectors would likely weigh in against the use of "dumps" to dispose of forward operating bases' (FOBs) waste. Also, worth consideration are the potential security concerns with unmanaged military waste specifically waste unit sizes and compositions estimated from food waste, or information gathered from trashed documents which can be aggregated to discern critical operational information. WTE technologies and unregulated landfills in arid environments are preferred expeditionary waste management options.

\subsection{Economic Analysis}

An impact factor not explored in SimaPro life-cycle assessments is the cost of the waste treatment scenarios. A high capital cost of WTE technologies has been a substantial obstacle to their acquisition and use. In this study, a financial anal- 
ysis was done in addition to the environmental LCA to carry out a more complete comparison of the four waste management scenarios. The costs include capital cost, annual operational and maintenance (O\&M) cost, annual benefits, and net present value (NPV) for 5,10 or 15 years. To compare costs, the requirements and contracts for expeditionary waste management in a deployed location were explored. In this study, the costs are reported on a per ton basis to facilitate comparisons.

Following the US congressional mandates to eliminate burn pits, the US Marine Corps shifted to incinerators to manage their waste. On Camp Leatherneck, the DoD spent 18 million US dollars (USD) to purchase and install four waste incinerators to meet the daily 54 tons of solid waste [49]. However, two of the incinerators were never used due to their high O\&M costs reaching approximately 1 million USD annually, and instead Camp Leatherneck chose to burn the wastes in open-air burn pits [49].

At a throughput of 54 tons of solid waste per day, using the same fuel to waste ratio used in this paper, this would require approximately 11,000 L (3000 gallons) of diesel fuel for the open-air burn pit each day and over 3.8 million L (1 million gallons) each year. At a very conservative 1.05 USD per L (4 USD per gallon) of diesel in the deployed environment, this is still over 4 million USD per year for the fuel to burn waste in an open-air burn pit, well above the estimated O\&M costs of the incinerator.

A local contract to landfill the waste instead of burning the waste in an openair pit, was investigated to potentially cost 1.1 million USD annually (SIGAR, 2015).

It was assumed the incineration WTE technology produced $1.09 \mathrm{GJ}$ of electricity per ton of waste (or 1.2 MJ per kg waste) designed in SimaPro's WTE models, a value confirmed in WEC's 2016 report of 8 - $12 \mathrm{MJ}$ per kg waste with $15 \%$ conversion efficiency. With 54 tons of received waste daily it could theoretically produce $5,972,500 \mathrm{kWh}$ per year as calculated by Equation (2).

$$
\begin{aligned}
& 1.09 \mathrm{GJ} /(\text { ton waste }) \times(54 \text { tons }) / \text { day } \times(365 \text { days }) / \text { year } \times(278 \mathrm{kWh}) / \mathrm{GJ} \\
& =5972500 \mathrm{kWh} \text { per year }
\end{aligned}
$$

Assuming electricity is produced by generators using diesel fuel, this could replace over 1.7 million L (450,000 gallons) of diesel (or 1.8 million USD of diesel fuel) to meet a similar electrical requirement (a $750 \mathrm{kWh}$ generator running 24 hours each day for an entire year would produce 6,500,000 kWh and use $202 \mathrm{~L}$ (53.4 gallons) of diesel per hour at maximum efficiency) [50].

An additional benefit of some WTE conversion technologies is the ability to safely convert hazardous waste such as used petroleum, oils, and lubricants (POLs), medical waste, and potentially batteries. The conversion of hazardous waste could save approximately 219 thousand USD annually for the transportation and landfilling of hazardous wastes [51].

The explored costs and benefits are summarized below in Table 1 using the US Federal Reserve Discount Rate of 3\%, an estimated 1.05 USD per L (4 USD 
Table 1. Economic analysis of the four waste management scenarios (waste management cost in millions of USD; negative values are costs).

\begin{tabular}{ccccccc}
\hline $\begin{array}{c}\text { Waste Management } \\
\text { Scenarios }\end{array}$ & $\begin{array}{c}\text { Capital } \\
\text { Cost }\end{array}$ & $\begin{array}{c}\text { Annual } \\
\text { O\&M }\end{array}$ & $\begin{array}{c}\text { Annual } \\
\text { Benefits }\end{array}$ & $\begin{array}{c}\text { NPV } \\
5 \text { Years }\end{array}$ & $\begin{array}{c}\text { NPV } \\
\text { 10 Years }\end{array}$ & $\begin{array}{c}\text { NPV } \\
15 \text { Years }\end{array}$ \\
\hline $\begin{array}{c}\text { Scenario 1: } \\
\text { WTE incineration }\end{array}$ & -18 & -1 & 2 & -13.420 & -9.470 & -6.062 \\
$\begin{array}{c}\text { Scenario 2 or 3: } \\
\text { Landfill (sanitary or } \\
\text { local unregulated) }\end{array}$ & 0 & -1.1 & 0 & -5.038 & -9.383 & -13.132 \\
$\begin{array}{c}\text { Scenario 4: } \\
\text { Open burn pits }\end{array}$ & 0 & -4.38 & 0 & -20.059 & -37.362 & -52.288 \\
\hline
\end{tabular}

per gallon) of diesel, and calculating the net present value (NPV) over 5, 10, and 15 years, approximating the length of the current Afghan War [52]. This was a very simplified cost analysis of the complex process, giving favorable assumptions to current US DoD scenarios.

Despite the inability to quantify the medical costs associated with exposure to open-air burn pits, the sheer cost of diesel fuel in their use makes them the least cost-effective means of expeditionary waste management. In this simplified cost analysis, contracted landfilling services were initially less costly than WTE conversion technologies due to the high capital costs of WTE technology. But the longer the waste management requirement, the more cost effective WTE technologies become, surpassing contracted services around the 10-year mark in this analysis. This cost difference will only become more substantial when considering the complete cost of fuel or rise in price of liquid fuels become substantial, driving up the price of open-air burning and increasing the benefits of WTE technologies with electricity generation. Considering these more expensive fuel scenarios would also see the cost effectiveness of WTE technologies exceed the other scenarios well before the 10-year mark, a time period that could easily be seen in the life-span of a US DoD contingency base. Also not considered in this analysis is the security concern with contracted services, opening the base to possible attack or the leaking of critical information via waste (papers, counts of sustenance materials, etc.).

Lastly, the many assumptions used throughout the study can obscure the results and affect the conclusions. Table 2 illustrates the possible impacts of the various assumptions.

When comparing the three main alternatives of WTE incineration, landfill, and open burn, the assumptions would tend to make open burn waste disposal appear less impactful than it might really be. However, the normalized comparison in Figure 2 still showed that open burn was the most impactful. In balance, the assumptions affecting the economic analysis would increase NPV for all scenarios. One note which would affect NPV was the previously-mentioned "fully-burdened cost of fuel." The use of a modest 1.05 USD/L cost for fuel would tend to underestimate the costs, resulting in a higher (less negative) NPV, 
Table 2. Assumptions made in LCA analysis for the four scenarios and effects of assumptions.

\begin{tabular}{|c|c|c|c|}
\hline $\begin{array}{c}\text { Waste management } \\
\text { Scenarios }\end{array}$ & Assumptions made & LCA Impacts $^{1}$ & NPV impacts ${ }^{2}$ \\
\hline Scenario 1: & $\mathrm{O} \& \mathrm{M}$ cost in AOR; & No impacts expected; & Increased NPV; \\
\hline $\begin{array}{l}\text { WTE } \\
\text { incineration }\end{array}$ & $\begin{array}{l}\text { Lifespan of systems } \\
\text { (15 years) }\end{array}$ & No impacts expected & Increased NPV \\
\hline \multirow{2}{*}{$\begin{array}{l}\text { Scenario 2: } \\
\text { Sanitary Landfill }\end{array}$} & $\begin{array}{l}\text { Meets developed world } \\
\text { standards; }\end{array}$ & Reduced LCA impacts; & Increased NPV; \\
\hline & Used 1.05 USD/L fuel & No impacts expected & Decreased NPV \\
\hline \multirow[t]{2}{*}{$\begin{array}{l}\text { Scenario 3: } \\
\text { Local } \\
\text { unregulated landfill }\end{array}$} & $\begin{array}{l}\text { No required } \\
\text { environmental } \\
\text { remediation }\end{array}$ & Increased LCA impacts & Increased NPV \\
\hline & Used 1.05 USD/L fuel; & No impacts expected; & Decreased NPV; \\
\hline \multirow{2}{*}{$\begin{array}{l}\text { Scenario } 4 \text { : } \\
\text { Open burn pits }\end{array}$} & No remediation; & Reduced LCA impacts; & Increased NPV; \\
\hline & $\begin{array}{l}\text { No control of disease } \\
\text { vectors }\end{array}$ & Reduced LCA impacts & Increased NPV \\
\hline
\end{tabular}

${ }^{1}$ Reduced LCA impacts make a scenario seem more beneficial based on the assumption, increased LCA impacts make a scenario seem less beneficial. ${ }^{2}$ Increased NPV make a scenario seem more economically beneficial (more positive in value) based on the assumption, decreased NPV makes a scenario seem less economically beneficial (more negative).

especially for open burn and sanitary landfill. In summary, the assumptions tended to make open burn more appealing in terms of impacts and costs. This strengthens the argument against open burn waste disposal.

\section{Conclusions}

The goal of this study was to compare the use of a WTE incineration facility, sanitary landfill, unregulated local landfills, and open burn pits in the management of expeditionary waste at deployed locations, from both an environmental as well as a financial perspective. The LCA analysis indicated the need to stop the open-air burning of waste. The dominance of impact results for open-air burning showed it as the most damaging expeditionary waste management option to human and environmental health. The cost of fuel required alone to burn the waste in open pits was more than the combined capital and O\&M costs of building and operating an incinerator (within five years), let alone the medical, legal, and administrative costs associated with the AH\&OBP Registry.

In comparison to unregulated landfilling which is associated with the very real threat of disease-carrying vectors and pests, WTE technologies have the lowest environmental and human health impacts of expeditionary waste management strategies. The results indicated that the use of an incineration facility performed better environmentally because the incineration facility produced electricity, and therefore a noticeably greater positive environmental offset. Considering the mitigated security risks and the net positive annual benefit of WTE incinerators with offset fuel costs and potential for generating heat and electricity, WTE in- 
cinerators may be the most economical expeditionary waste management strategy for prolonged waste management scenarios, especially considering the fully-burdened cost of fuels and the uncertainty in price of liquid fuels. When consideration is given to all potential costs and benefits of a waste management strategy, WTE technology's mitigated human and environmental health impacts and cost effectiveness make them a viable expeditionary waste management strategy for US DoD contingency bases.

Therefore, in order for the results to remain relevant, future LCAs should be done as new waste diversion initiatives are launched or as new waste management technologies become mainstream. Other assumptions included the omissions of the effects of ancillary processes and of leachate treatment for both the hazardous ash and landfill. The processes should be included in future studies to improve the completeness of the analysis. Furthermore, this study considered electricity as the only form of energy recovery for simplification purposes, however, the effects of other forms of energy recovery systems, such as combined heat and power, should be explored further.

\section{Acknowledgements}

This work was supported by a grant from the US Air Force Civil Engineer Center.

\section{Disclaimers}

The views expressed in this paper are those of the authors and do not reflect the official policy or position of the US Air Force, the US Marine Corps, the US Department of Defense, or the US government.

\section{Conflicts of Interest}

The authors declare no conflicts of interest regarding the publication of this paper.

\section{References}

[1] Rushton, L. (2003) Health Hazards and Waste Management. British Medical Bulletin, 68, 183-197. https://doi.org/10.1093/bmb/ldg034

[2] Macias, K. (2015) Navy SBIR 2015.2-Topic N152-097 Low Emissions Waste to Energy Disposal. Navy Facilities Engineering Command.

[3] Relph, E. and Chiang, T. (2016) Waste-to-Energy Thermal Destruction Identification for Forward Operating Bases. Navy Facilities Engineering Command, Engineering and Expeditionary Warfare Center. https://apps.dtic.mil/dtic/tr/fulltext/u2/1038762.pdf

[4] VA (2020) VA's Airborne Hazards and Open Burn Pit Registry. U.S. Department of Veterans Affairs. https://www.publichealth.va.gov/exposures/burnpits/registry.asp

[5] VA (2015) Report on Data from the Airborne Hazards and Open Burn Pit (AH \& OBP) Registry. U.S. Department of Veterans Affairs, Veterans Health Administration, Office of Public Health.

https://www.publichealth.va.gov/docs/exposures/va-ahobp-registry-data-report-apr il2015.pdf

[6] 40 U.S.C. (2010) US Code Title 40. Part 258-Criteria for Municipal Solid Waste Landfills. 
[7] DoD (2017) DoDI 4715.19 Use of Open-Air Burn Pits in Contingency Operations. Department of Defnese Instruction. Department of Defense.

[8] Mukherjee, C., Denney, J., Mbonimpa, E.G., Slagley, J. and Bhowmik, R. (2020) A Review on Municipal Solid Waste-to-Energy Trends in the USA. Renewable and Sustainable Energy Reviews, 119, Article ID: 109512. https://doi.org/10.1016/j.rser.2019.109512

[9] DoD (2016) DoD Instruction 4715.23 Integrated Recycling and Solid Waste Management. Office of the Under Secretary of Defense for Acquisition, Technology, and Logistics.

[10] Knowlton, L. (2013) Small-Scale Waste to Energy. US Army Natick Soldier RD\&E Center. Joint Deployable Waste to Energy (JDW2E).

[11] Novotny, C. (2017) Implementing Waste Disposal Alternatives in Overseas Contingency Operations. Office of the Deputy Assistant Secretary of Defense (Environment, Safety \& Occupational Health). https://apps.dtic.mil/dtic/tr/fulltext/u2/1051872.pdf

[12] Hwang, K.-L., Choi, S.-M., Kim, M.-K., Heo, J.-B. and Zoh, K.-D. (2017) Emission of Greenhouse Gases from Waste Incineration in Korea. Journal of Environmental Management, 196, 710-718. https://doi.org/10.1016/j.jenvman.2017.03.071

[13] Moya, D., Aldás, C., López, G. and Kaparaju, P. (2017) Municipal Solid Waste as a Valuable Renewable Energy Resource: A Worldwide Opportunity of Energy Recovery by Using Waste-to-Energy Technologies. Energy Procedia, 134, 286-295. https://doi.org/10.1016/j.egypro.2017.09.618

[14] Mühle, S., Balsam, I. and Cheeseman, C.R. (2010) Comparison of Carbon Emissions Associated with Municipal Solid Waste Management in Germany and the UK. Resources, Conservation \& Recycling, 54, 793-801. https://doi.org/10.1016/j.resconrec.2009.12.009

[15] EPA (2017) Energy Recovery from the Combustion of Municipal Solid Waste (MSW). https://www.epa.gov/smm/energy-recovery-combustion-municipal-solid-waste-ms w\#EnergyRecovery

[16] WEC (2016) World Energy Resources-Waste to Energy. World Energy Council. https://www.worldenergy.org/assets/images/imported/2016/10/World-Energy-Reso urces-Full-report-2016.10.03.pdf

[17] Harris, E., Zeyer, K., Kegel, R., Müller, B., Emmenegger, L. and Mohn, J. (2015) Nitrous Oxide and Methane Emissions and Nitrous Oxide Isotopic Composition from Waste Incineration in Switzerland. Waste Management, 35, 135-140. https://doi.org/10.1016/j.wasman.2014.10.016

[18] Liamsanguan, C. and Gheewala, S.H. (2008) LCA: A Decision Support Tool for Environmental Assessment of MSW Management Systems. Journal of Environmental Management, 87, 132-138. https://doi.org/10.1016/j.jenvman.2007.01.003

[19] Arena, U., Mastellone, M.L. and Perugini, F. (2003) The Environmental Performance of Alternative Solid Waste Management Options: A Life Cycle Assessment Study. Chemical Engineering Journal, 96, 207-222. https://doi.org/10.1016/j.cej.2003.08.019

[20] ISO (2006) ISO 14040:2006 Environmental Management-Life Cycle AssessmentPrinciples and Framework. International Organization for Standardization.

[21] Cleary, J. (2009) Life Cycle Assessments of Municipal Solid Waste Management Systems: A Comparative Analysis of Selected Peer-Reviewed Literature. Environment International, 35, 1256-1266. https://doi.org/10.1016/j.envint.2009.07.009

[22] Theis, J. and Tomkin, T. (2013) Sustainability-A Comprehensive Foundation. U of 
I Open Source Textbook Initiative.

[23] Ekvall, T., Assefa, G., Björklund, A., Eriksson, O. and Finnveden, G. (2007) What Life-Cycle Assessment Does and Does Not Do in Assessments of Waste Management. Waste Management, 27, 989-996. https://doi.org/10.1016/j.wasman.2007.02.015

[24] PRé (2019) About SimaPro. https://simapro.com

[25] Kaushal, V. and Najafi, M. (2020) Comparative Assessment of Environmental Impacts from Open-Cut Pipeline Replacement and Trenchless Cured-in-Place Pipe Renewal Method for Sanitary Sewers. Infrastructures, 5, 48. https://doi.org/10.3390/infrastructures5060048

[26] PRé (2016) Introduction to LCA with SimaPro. https://www.pre-sustainability.com/download/SimaPro8IntroductionToLCA.pdf

[27] PRé (2016) SimaPro Database Manual. https://simapro.com/wp-content/uploads/2020/10/DatabaseManualMethods.pdf

[28] Ecoinvent. FAQs. https://www.ecoinvent.org/support/faqs/methodology-of-ecoinvent-3/what-do-theshortcuts-such-as-ch-rer-row-and-glo-mean.html

[29] Forouhar, C. and Peterson, A. (2007) Out of the Shadows. Waste Management World. https://waste-management-world.com/a/out-of-the-shadows

[30] EPA (2008) Background Information Document for Updating AP42 Section 2.4 for Estimating Emissions from Municipal Solid Waste Landfills. U.S. Environmental Protection Agency.

[31] EPA (2005) Landfill Gas Emissions Model (LandGEM) Version 3.02 User's Guide. U.S. Environmental Protection Agency.

[32] Petrescu, B., Batrinescu, M. and Stanescu, G. (2011) Evaluation of Gaseous Emissions from the Radauti Municipal Landfill. International Journal of Conservation Science, 2, 45-54.

[33] Durmusoglu, E., Taspinar, F. and Karademir, A. (2010) Health Risk Assessment of BTEX Emissions in the Landfill Environment. Journal of Hazardous Materials, 176, 870-877. https://doi.org/10.1016/j.jhazmat.2009.11.117

[34] Johansen, O.J. and Carlson, D.A. (1976) Characterization of Sanitary Landfill Leachates. Water Research, 10, 1129-1134. https://doi.org/10.1016/0043-1354(76)90046-4

[35] Kulikowska, D. and Klimiuk, E. (2008) The Effect of Landfill Age on Municipal Leachate Composition. Bioresource Technology, 99, 5981-5985.

https://doi.org/10.1016/j.biortech.2007.10.015

[36] Christensen, T.H., et al. (2001) Biogeochemistry of Landfill Leachate Plumes. Applied Geochemistry, 16, 659-718. https://doi.org/10.1016/S0883-2927(00)00082-2

[37] Mali, S.T. and Patil, S.S. (2016) Life-Cycle Assessment of Municipal Solid Waste Management. Proceedings of the Institution of Civil Engineers-Waste and Resource Management, 169, 181-190. https://doi.org/10.1680/jwarm.16.00013

[38] Ogundipe, O.D. and Jimoh, F.O. (2015) Life Cycle Assessment of Municipal Solid Waste Management in Minna, Niger State, Nigeria. International Journal of Environmental Research, 9, 1305-1314.

[39] Climate-Data.org (2020) Climate Lashkar Gah. https://en.climate-data.org/asia/afghanistan/helmand/lashkar-gah-3833

[40] Fenn, T.V., Hanley, D.G. and DeGeare, K.J. (1975) Use of the Water Balance Method for Predicting Leachate Generation from Solid Waste Disposal Sites. Office of Solid Waste Management Programs. U.S. Environmental Protection Agency. 
https://nepis.epa.gov/Exe/ZyPURL.cgi?:Dockey=9100OH2M.TXT

[41] Brennan, R.B., Healy, M.G., Morrison, L., Hynes, S., Norton, D. and Clifford, E. (2016) Management of Landfill Leachate: The Legacy of European Union Directives. Waste Management, 55, 355-363. https://doi.org/10.1016/j.wasman.2015.10.010

[42] Hornstein, T. (2018) Life Cycle Analysis of Waste-to-Energy Conversion Technologies for Contingency DoD Deployed Forces. Air Force Institute of Technology, Air University, Air Education and Training Command.

[43] Tchobanoglous, S., Theisen, G. and Vigil, H. (1993) Integrated Solid Waste Management-Engineering Principles and Management Issues. McGraw-Hill Inc., New York.

[44] Aurell, B. and Gullett, J. (2017) Characterization of Air Emissions from Open Burning at the Radford Army Ammunition Plant. RAAP Reports \& Documents. Virginia Department of Environmental Quality.

[45] Dominguez, T., Aurell, J., Gullett, B., Eninger, R. and Yamamoto, D. (2018) Characterizing Emissions from Open Burning of Military Food Waste and Ration Packaging Compositions. Journal of Material Cycles and Waste Management, 20, 902-913. https://doi.org/10.1007/s10163-017-0652-y

[46] Woodall, B.D., Yamamoto, D.P., Gullett, B.K. and Touati, A. (2012) Emissions from Small-Scale Burns of Simulated Deployed U.S. Military Waste. Environmental Science \& Technology, 46, 10997-11003. https://doi.org/10.1021/es3021556

[47] Gerstle, R.W. and Kemnitz, D.A. (2012) Atmospheric Emissions from Open Burning. Journal of the Air Pollution Control Association, 17, 324-327. https://doi.org/10.1080/00022470.1967.10468988

[48] EPA (1996) AP 42: Compilation of Air Pollutatnt Emission Factors, Fifth Edition, Volume I, Chapter 2 Solid Waste Disposal 2.1 Refuse Combustion. U.S. Environmental Protection Agency.

[49] SIGAR (2015) Final Assessment: What We Have Learned from Our Inspections of Incinerators and Use of Burn Pits in Afghanistan. Special Inspector General for Afghanistan Reconstruction, Arlington. https://www.sigar.mil/pdf/alerts/SIGAR-15-33-AL.pdf

[50] Diesel Supply Services (2018) Approximate Diesel Fuel Consumption. https://www.dieselserviceandsupply.com/Diesel_Fuel_Consumption.aspx

[51] DLA (2017) Defense Logistics Agency (DLA) Deployable Hazardous Waste Disposal Project Rough Order of Magnitude (ROM) Business Case Analysis (BCA). Defense Logistics Agency J34, Strategic Distribution \& Disposition, Research \& Development.

[52] Federal Reserve (2019) The Discount Rate. Board of Governors of the Federal Reserve System. https://www.federalreserve.gov/monetarypolicy/discountrate.htm

\section{Supplementary Data}

Supplementary data is associated with this article. https://doi.org/10.13140/RG.2.2.25748.42888. 